\section{Performance on neurological development tests by riverine children with moderate mercury exposure in Amazonia, Brazil}

\author{
Desempenho de crianças ribeirinhas \\ da Amazônia, Brasil, expostas moderadamente \\ ao mercúrio em testes para avaliação \\ de desenvolvimento neurológico
}

\author{
1 Fundação Nacional da \\ Saúde, Ministério da Saúde, \\ Cuiabá, Brasil. \\ 2 Núcleo de Estudos de Saúde \\ Coletiva, Universidade \\ Federal do Rio de Janeiro, \\ Rio de Janeiro, Brasil. \\ 3 Instituto de Biofísica, \\ Universidade Federal \\ do Rio de Janeiro, \\ Rio de Janeiro, Brasil. \\ 4 Seção de Meio Ambiente, \\ Instituto Evandro Chagas, \\ Belém, Brasil. \\ Correspondence \\ V. M. Câmara \\ Núcleo de Estudos de Saúde \\ Coletiva, Universidade \\ Federal do Rio de Janeiro. \\ Praça da Prefeitura \\ da Cidade Universitária, \\ Rio de Janeiro, $R J$ \\ 21949-900, Brasil. \\ volney@nesc.ufrj.br
}

\begin{abstract}
The nervous system can be damaged when the population is exposed to methyl mercury (MeHg) by ingesting fish, and children deserve special attention due to their increased susceptibility as compared to adults. A comparative cross-sectional study was performed in order to investigate the use of a battery of neurological development tests in two groups of 209 riverine children from 3 to 7 years old: a group exposed to moderate levels of MeHg $(n=75)$ and a control group $(n=134)$. The study included a questionnaire, the collection of scalp hair samples for determination of total mercury concentration, and performance on a test for evaluating neurological function in children. Riverine children presented higher exposure to $\mathrm{MeHg}$ (mean hair $\left.\mathrm{Hg}=5.37 \pm 3.35 \mu \mathrm{g} . \mathrm{g}^{-1}\right)$ in comparison to the control group (mean $\mathrm{Hg}=2.08 \pm 1.37 \mu g . g^{-1}$ ). Both groups showed a high proportion of children with what was considered "non-normal" performance, suggesting that the results could not be related to mercury exposure and that this type of test presented limitations for use with river-dwelling Amazon communities.
\end{abstract}

Mercury; Mercury Poisoning; Nervous System; Child
Lydia Maria Bocayuva Tavares 1 Volney Magalhães Câmara ${ }^{2}$ Olaf Malm 3

Elisabeth C. de Oliveira Santos 4

\section{Introduction}

Under special conditions, such as the presence of microorganisms and algae in water compartments, $\mathrm{pH}$, temperature, and others, mercury can be transformed into methyl mercury (MeHg) - the most toxic form of this metal and concentrate in fish along the food chain 1,2 .

The general population is exposed to $\mathrm{MeHg}$ through food consumption, especially by ingesting fish 2 . MeHg is easily absorbed by the digestive tract, reaching the bloodstream and finally various tissues in the human body, particularly the nervous system, in addition to its capacity to cross the placental barrier and cause fetal damage or malformations. After birth, children can also be exposed by ingesting breast milk contaminated with this metal. The adverse effects on the nervous system in children include loss of motor coordination, developmental deficits that affect speech and movement, and decreased intelligence quotient 3,4 .

Children's greater susceptibility to chemical substances, especially metals, can be caused by various factors, for example the greater possibility of absorption through the skin and digestive tract and the immaturity of the blood-brain barrier 4,5,6. Thus, children represent a priority group for studies on exposure and the adverse health effects of chemical pollution.

The majority of studies of mercury exposure in areas in the Brazilian Amazon which used 
psychiatric or neurological evaluation have focused on riverine populations in the Tapajós Basin, which presented mean hair mercury concentrations greater than $10 \mu \mathrm{g} . \mathrm{g}^{-1}$. These studies did not find individuals with clinical characteristics of mercury poisoning 7,8,9.

There are still few studies on children with chronic and moderate exposure to low concentrations of mercury 10,11,12. In the Amazon, efforts are being made to evaluate signs of neurological dysfunction that could serve as early indicators of mercury poisoning in river-dwellers 13. A possible limitation to conducting these tests is that they require perception and understanding of the motor activity to be performed, plus the fact that they were developed and validated for populations with different social, cultural, and economic characteristics from those of the river-dwelling communities.

The current study thus sought to assess the possibility of using neurological development tests to compare two homogeneous groups of riverine children from the Brazilian Amazon with different levels of mercury exposure. Although the tests to be applied had not been validated for riverine children, comparison of the two groups with similar social and economic levels was expected to allow investigating whether greater exposure to $\mathrm{Hg}$ could result in performance differences on these tests.

\section{Materials and methods}

A comparative cross-sectional study was conducted on riverine children from 3 to 7 years of age exposed to moderate levels of $\mathrm{MeHg}$ in the municipality (county) of Barão de Melgaço, State of Mato Grosso, Brazil, to investigate the use of a battery of neurological development assessment tests validated by Lefèvre 14. Participation in the study group included all possible children living in four riverside communities along the Rio Cuiabá: Boca de Conchas, Cuiabá Mirim, Estirão Cumprido, and Porto Brandão. Residents of these communities eat fish as their main food source. Exclusion criteria were children who had lived previously in other municipalities, who had presented neurological or psychiatric diseases since birth, and other genetically transmitted diseases that might interfere in the test results.

The control group consisted of children 3 to 7 years of age who were also river-dwellers, living in the town of Barão de Melgaço, with so- cioeconomic standards similar to those of the study group 15 . They were differentiated from the study group principally by the lower dependency on fish as their source of food protein.

Barão de Melgaço, a county situated in the Alto Pantanal micro-region in Mato Grosso, $77.3 \mathrm{~km}$ from the State capital of Cuiabá, has fishing and tourism as the main sources of income, and it was the location chosen for this study because it has a riverine community where fish is the principal source of protein and because it does not present any other economic activity that could cause direct exposure to mercury or pesticides. The population is considered stable, and in the last census it had a total de 7,682 inhabitants, of whom 1,071 were riverdwellers 16 . It can be considered a location with predominantly moderate exposure to mercury as compared to other communities in the Amazon 16 .

Although Barão de Melgaço does not produce gold, its proximity to mining areas in other locations in the Pantanal could explain the existence of mercury exposure. Another possibility for Hg exposure would be the presence, in the Rio Cuiabá, of particulate matter resulting from the erosion caused by such factors as farming, dredging, and slashing and burning in the river basin. Another factor for exposure could be the mercury launched into the river by the Cuiabá city sewage system 1,17. In some sites such as the Siá Mariana bay, a study concluded that there was a high potential for mercury methylation 1 .

The present study was conducted according to the ethical standards of Ruling 196/96 of the Brazilian National Health Council, including signing a free informed consent form by parents or guardians of the children. The following procedures were followed: (a) identification of 88 riverine children from fishing villages ranging from 3 to 7 years and eligible for the study through a prior census and 222 riverine children from the urban area of the municipality of Barão de Melgaço through census maps supplied by the Brazilian Institute of Geography and Statistics (IBGE); (b) application of a questionnaire including data on identification, nutritional habits, and disease history with an emphasis on the prevalence of signs and symptoms related to mercury poisoning, answered by the parents or guardians of the children; (c) collection of scalp hair samples using a non-oxidized metal scissors and subsequently stored at room temperature in white envelopes 
until analysis; (d) determination of total mercury by the Radioisotopes Laboratory at the Institute of Biophysics, Federal University in Rio de Janeiro, using atomic absorption spectrophotometry according to the continuous-flow cold vapor generation technique (FIMS-Perkin Elmer) 18. This laboratory uses international procedures and programs for analytical quality assessment and routinely uses IAEA 085 and 086 reference materials. The technique's detection limit for hair samples, calculated as three times the value of blanks multiplied by the dilution factor (final volume of the extract divided by the sample's mass) was $0.035 \mu \mathrm{g} . \mathrm{g}^{-1}$ and the quantification limit calculated as three times this value would be $0.105 \mu \mathrm{g} . \mathrm{g}^{-1}$; (e) Application of the neurological development test.

The main criteria for choice of the Lefèvre Evolutional Neurological Test were its easy execution; validation in children from a Brazilian city; applicability to an age bracket less studied in the Brazilian Amazon in terms of mercury effects; and the fact that it did not depend on technological resources in such a way as to prevent its use in a location without electricity. These motor and sensory neurological development tests had been validated by Lefèvre and a group of neuropediatricians who applied 124 different tests in two hundred children from 3 to 7 years of age from both sexes selected from a total of 755 children living in São Paulo and considered "normal" by their families, schools, or daycare centers. As a result, appropriate tests were established for each age 14 . Some of these tests were applied in this study, including those for evaluation of appendicular coordination, static balance, dynamic balance, trunk-limb coordination, motor persistence, and sensory perception. Table 1 describes the procedures for performing each test according to the child's age.

The collected data were stored in a microcomputer using Epi Info 2000, and the statistical tests included the $t$-test for two independent samples with unequal variances and the chi-square test for comparing proportions.

\section{Results and discussion}

Participation included 209 children, 75 in the target group and 134 in the control group, who were accompanied by their parents and community leaders and members of the Melgassense Ecology Association (AMEC) in an appropriate site (public school) for performing the test, thus representing minor losses as compared to the total number of eligible children. Of these children, two twins were excluded from the study group because they presented neurological signs and symptoms caused by birth hypoxia, so that 73 children from this riverine community remained in the study from birth onward.

Table 2 shows the data on mercury exposure based on scalp hair Hg concentration and weekly ingestion of fish. Losses of hair samples occurred because according to mothers' reports, some of the boys had asked to have their heads shaved in the style imitating the world's most valuable soccer player that year, Brazilian star striker Ronaldo, and also as a way of preventing infestation by head lice (Pediculus capitis).

Based on the statistics concerning hair mercury concentration and ingestion of fish, we observed that the river-dwelling children in the study group showed higher mercury exposure. Comparison of total mercury concentrations in the two groups showed a highly significant difference based on the $t$-test for two samples with unequal variances $(t=87.32$ and $\mathrm{p}=0.000)$ between the mean for the children from the study group $\left(5.37 \pm 3.35 \mu \mathrm{g}\right.$. $\left.\mathrm{g}^{-1}\right)$ and the control group $\left(2.08 \pm 1.37 \mu \mathrm{g} . \mathrm{g}^{-1}\right)$. The number of samples was not a limitation for these statistical analyses, possibly because the data variance was very slight in the control group (1.87). In addition, the study group showed a higher median

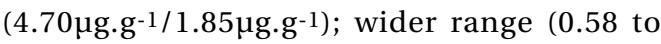
$17.14 \mu$ g.g-1/n.d. up to $7.57 \mu$ g.g-1); and more samples greater than $6.0 \mu \mathrm{g} \cdot \mathrm{g}^{-1}(22 / 2)$.

These results characterize moderate mercury exposure when compared to those found in other riverine communities in the Tapajós Basin by Santos et al. 7 : mean hair Hg of $19.91 \mu \mathrm{g}$.g-1

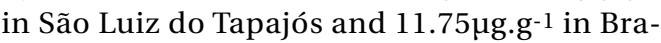
sília Legal. They are similar to those observed in a previous study with 129 subjects including children over 6 years of age and adults in Barão de Melgaço, showing a mean mercury concentration of $4.20 \pm 2.4 \mu \mathrm{g}$.g-1 in hair 16 . The results were also similar to those found in two other international studies in children chronically exposed to moderate mercury levels: on the Seychelles Islands 11 the mean $\mathrm{Hg}$ in hair was $6.5 \mu \mathrm{g} . \mathrm{g}^{-1}$ and on the Faroe Islands 12 the range was 2.6 to $7.7 \mu \mathrm{g} . \mathrm{g}-1$.

Another complementary indicator of greater mercury exposure in the study group was the mean weekly consumption of fish $(7.77$ versus 4.60 times a week), representing a statistical difference $(t=26.48$ and $\mathrm{p}=0.000001)$ using the $t$-test for two means with unequal variances. According to authors like Nakagawa 19, mercury exposure levels are generally higher in individuals who consume more fish. Additionally, according to reports by the mothers of these 
Description of neurological development tests according to age. Barão de Melgaço, Mato Grosso, Brazil, 2001.

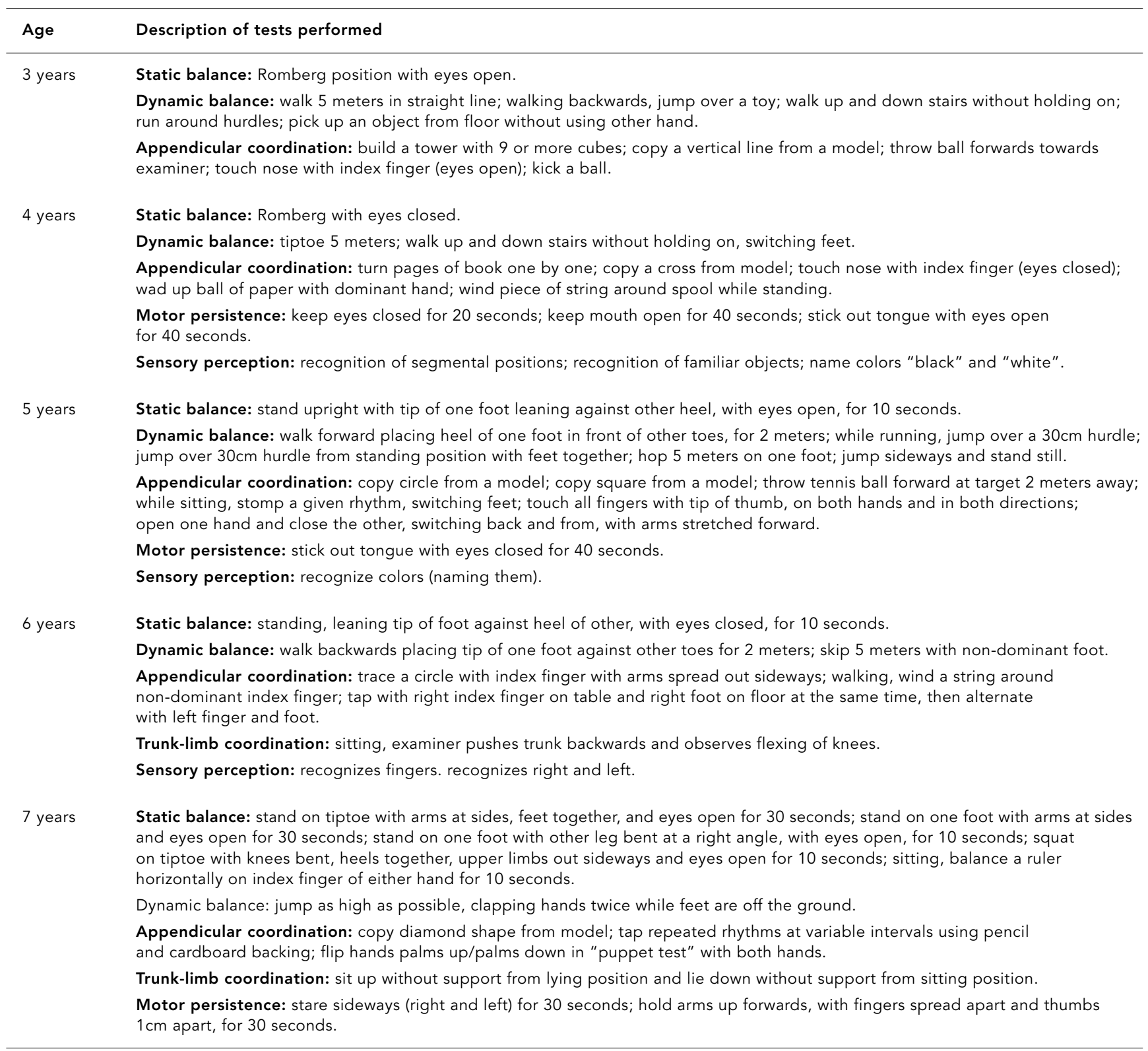

Source: Lefèvre 14 .

children, carnivorous fish were consumed more frequently in the study group as compared to the control group ( $62.7 \%$ versus $49.2 \%$ ).

In the clinical examination, no signs and symptoms were found that could jointly reflect a clinical picture characteristic of mercury poisoning.

Table 3 shows the children's performance on the Neurological Development Tests according to age, with three performance categories for each test: "normal", "non-normal", and "refusal". The proportion of children who refused to perform the tests was higher in the study group as compared to the control group, with the following values, respectively, for static balance (12.3\% and $6.0 \%)$; dynamic balance (15.1\% and $8.9 \%)$; appendicular coordination (13.7\% and $10.4 \%)$; motor persistence $(12.5 \%$ and $6.7 \%)$; trunk-limb coordination $(7.3 \%$ and $6.7 \%$ ); and sensory perception ( $16.3 \%$ and $6.7 \%$ ).

Even considering that these tests had been validated in children classified as "normal" in 


\section{Table 2}

Descriptive measures of scalp hair mercury concentration and fish intake by study groups. Barão de Melgaço, Mato Grosso, Brazil, 2001.

\begin{tabular}{|c|c|c|}
\hline & Riverine children & Controls \\
\hline \multicolumn{3}{|l|}{ Scalp hair mercury } \\
\hline Number of persons & 72 & 114 \\
\hline Mean & $5.37 \mu \mathrm{g} \cdot \mathrm{g}^{-1}$ & $2.08 \mu \mathrm{g} \cdot \mathrm{g}^{-1}$ \\
\hline Standard deviation & 3.35 & 1.37 \\
\hline Variance & 11.2 & 1.87 \\
\hline Range & $0.58-17.14 \mu \mathrm{g} \cdot \mathrm{g}^{-1}$ & $0.385-7.57 \mu \mathrm{g} \cdot \mathrm{g}^{-1}$ \\
\hline Median & $4.70 \mu \mathrm{g} \cdot \mathrm{g}^{-1}$ & $1.85 \mu \mathrm{g} \cdot \mathrm{g}^{-1}$ \\
\hline Samples $>6.0 \mu \mathrm{g} \cdot \mathrm{g}^{-1}$ & 22 & 2 \\
\hline \multicolumn{3}{|l|}{ Mean weekly fish intake } \\
\hline Number of persons & 73 & 133 \\
\hline Mean & 7.77 times & 4.60 times \\
\hline Standard deviation & 4.83 & 3.86 \\
\hline Range & $1-14$ times & $0-21$ times \\
\hline Variance & 23.32 & 14.92 \\
\hline \multicolumn{3}{|c|}{ Type of fish consumed (first choice) } \\
\hline Carnivorous & $47(62.7 \%)$ & $67(49.2 \%)$ \\
\hline Non-carnivorous & $22(29.4 \%)$ & $51(37.6 \%)$ \\
\hline Unspecified & $6(8.0 \%)$ & $18(13.2 \%)$ \\
\hline
\end{tabular}

Statistical analysis using t-test, Satterthwaite method for two independent samples with unequal variances:

Mean scalp hair mercury by group $=t=87.32$ and $p=0.000000$;

Mean weekly fish intake $=t=26.48$ and $p=0.000001$. would not be appropriate for indicating effects on the nervous system in riverine children with moderate mercury exposure. Second, that it is necessary to validate specific tests for riverine populations.

Studies in other populations also failed to observe conclusive results as to the neurological effects of moderate mercury exposure. A survey was conducted on the Seychelles Islands with 708 children whose mothers had been exposed to $\mathrm{MeHg}$ through ingestion of fish, and no effects were found on the physical development of these children 10. On the Faroe Islands, Grandjean et al. 11 used neurological tests and clinical examination and found no motor function abnormalities that could be related to mercury exposure in 1,022 children whose mothers were exposed to this metal through ingestion of whale meat during pregnancy. Recently, in French Guiana, a neurological and neuropsychological evaluation of 153 children in Amerindian communities found no relevant signs of mercury poisoning 12 .

There is evidence that the riverine population investigated in the current study, as well as other river-dwelling populations, present unfavorable socioeconomic indicators, for example referring to income, schooling, and lack of basic public services infrastructure 16,20. During this study period, there was no electricity in the four communities in the study group. In Barão de Melgaço the infant mortality rate was 38.9 per thousand live births, life expectancy at birth was 65.6 years, and the municipal urban development index was 0.67215 . This of course meant less access to information. One could suppose that these living conditions, together with the cultural patterns characterizing isolated populations, could be contributing factors to this type of response to the tests. Mergler 21, comparing studies performed in Brazil and Canada, observed that cultural and formal schooling differences in the Amazon prevented one from affirming that negative cognitive test results might be associated with Hg exposure.

The ideas of Amazon peoples in general, and particularly those of children, present a strong component of distrust when asked questions by outsiders (strangers), a factor which might have altered the responses to the applied tests, thus inducing investigator interpretation errors. According to studies on socio-historical aspects of Amazon river-dwellers 22,23, these peoples are descendents of Indians, blacks, and whites and have been heavily affected by social, economic, and cultural factors since the European colonization process in the $17^{\text {th }}$ century until recently through the implantation of 
Neurological development tests in study groups, by age. Barão de Melgaço, Mato Grosso, Brazil, 2001.

\begin{tabular}{|c|c|c|c|c|c|c|c|c|c|c|c|c|c|c|}
\hline & \multicolumn{7}{|c|}{ Study group by age $(n=73)$} & \multicolumn{7}{|c|}{ Control group by age $(n=134)$} \\
\hline & \multirow[t]{2}{*}{3} & \multirow[t]{2}{*}{4} & \multirow[t]{2}{*}{5} & \multirow[t]{2}{*}{6} & \multirow[t]{2}{*}{7} & \multicolumn{2}{|c|}{ Total } & \multirow[t]{2}{*}{3} & \multirow[t]{2}{*}{4} & \multirow[t]{2}{*}{5} & \multirow[t]{2}{*}{6} & \multirow[t]{2}{*}{7} & \multicolumn{2}{|c|}{ Total } \\
\hline & & & & & & $\mathrm{n}$ & $\%$ & & & & & & $\mathrm{n}$ & $\%$ \\
\hline \multicolumn{15}{|l|}{ Static balance } \\
\hline Non-normal & 1 & 0 & 4 & 3 & 4 & 12 & 16.4 & 1 & 4 & 4 & 12 & 3 & 24 & 17.9 \\
\hline Refusal & 2 & 3 & 2 & 2 & 0 & 9 & 12.3 & 2 & 2 & 0 & 2 & 2 & 8 & 6.0 \\
\hline Normal & 2 & 8 & 12 & 15 & 15 & 52 & 71.3 & 17 & 20 & 21 & 25 & 19 & 102 & 76.1 \\
\hline \multicolumn{15}{|c|}{ Dynamic balance } \\
\hline Non-normal & 0 & 1 & 3 & 8 & 7 & 19 & 26.0 & 5 & 1 & 6 & 18 & 6 & 36 & 26.9 \\
\hline Refusal & 2 & 2 & 4 & 2 & 1 & 11 & 15.1 & 5 & 2 & 1 & 2 & 2 & 12 & 8.9 \\
\hline Normal & 3 & 8 & 11 & 10 & 11 & 43 & 58.9 & 10 & 23 & 18 & 19 & 16 & 86 & 64.2 \\
\hline \multicolumn{15}{|c|}{ Appendicular coordination } \\
\hline Non-normal & 0 & 4 & 8 & 9 & 9 & 30 & 41.1 & 7 & 7 & 14 & 15 & 11 & 54 & 40.3 \\
\hline Refusal & 2 & 1 & 4 & 2 & 1 & 10 & 13.7 & 5 & 4 & 1 & 2 & 2 & 14 & 10.4 \\
\hline Normal & 3 & 6 & 6 & 9 & 9 & 33 & 45.2 & 8 & 15 & 10 & 22 & 11 & 66 & 49.3 \\
\hline \multicolumn{15}{|c|}{ Motor persistence } \\
\hline Non-normal & * & 2 & 1 & * & 7 & 10 & 20.8 & * & 2 & 2 & * & 9 & 13 & 17.3 \\
\hline Refusal & * & 3 & 2 & * & 1 & 6 & 12.5 & * & 2 & 1 & * & 2 & 5 & 6.7 \\
\hline Normal & * & 6 & 15 & * & 11 & 32 & 66.7 & * & 22 & 22 & * & 13 & 57 & 76.0 \\
\hline \multicolumn{15}{|c|}{ Trunk-limb coordination } \\
\hline Non-normal & * & * & * & 5 & 5 & 10 & 24.4 & * & * & * & 9 & 3 & 12 & 19.0 \\
\hline Refusal & * & * & * & 2 & 1 & 3 & 7.3 & * & * & * & 2 & 2 & 4 & 6.4 \\
\hline Normal & * & * & * & 15 & 13 & 28 & 68.3 & * & * & * & 28 & 19 & 47 & 74.6 \\
\hline \multicolumn{15}{|c|}{ Sensory perception } \\
\hline Non-normal & * & 3 & 9 & 7 & * & 19 & 38.8 & * & 12 & 11 & 12 & * & 35 & 38.9 \\
\hline Refusal & * & 2 & 3 & 3 & * & 8 & 16.3 & * & 3 & 1 & 2 & * & 6 & 6.7 \\
\hline Normal & * & 6 & 6 & 10 & * & 22 & 44.9 & * & 11 & 13 & 25 & * & 49 & 54.4 \\
\hline
\end{tabular}

* Not applicable for this age.

Chi-square test (Yates corrected): non-normal/normal: static balance $\left(\chi^{2}=0.02 ; p=0.88\right)$;

dynamic balance $\left(\chi^{2}=0.00 ; p=0.99\right)$; appendicular coordination $\left(\chi^{2}=0.03 ; p=0.86\right)$;

motor persistence $\left(\chi^{2}=0.18 ; p=0.67\right)$; trunk-limb coordination $\left(\chi^{2}=0.19 ; p=0.60\right)$;

and sensory perception $\left(\chi^{2}=0.09 ; p=0.76\right)$.

development programs in the Amazon. Arenz 22 (p. 76) also shows that the deep changes occurring as a result of this process have affected, but not included, the riverine population: "suspicious and exhausted after years of struggle, many river-dwellers have stayed away from the towns and cities". This distrust of strangers was also emphasized by Coimbra Jr. 24 when he evaluated the origins and adaptations of native Amazonian peoples and reported on the difficulties in performing epidemiological studies among these native peoples, particularly emphasizing "the population's occasional aggressive reactions to intruders" (p. 180).

\section{Conclusions}

Based on the analysis of $\mathrm{Hg}$ levels in scalp hair, the river-dwelling community studied here presents moderate mercury exposure as compared to other communities in the Brazilian Amazon and also a significantly greater exposure than the control group chosen from the same county.

Although the effects of mercury in this population cannot be ruled out, the performance on six types of tests presented a high number of children classified as "non-normal" in both the study and control groups. Thus, the children's negative performance on test development could not be explained by higher mercury exposure. 
While considering the limitations of inferring these results to the entire Brazilian Amazon, this study alerted us to the need for caution in the analysis of studies involving early effects on the nervous system in riverine children based on their performance in neurological test batteries. The importance of other variables should also be evaluated, including social, economic, and cultural factors that could potentially influence the children's performance on this type of test.

\section{Resumo}

O sistema nervoso pode ser afetado quando as pessoas, notadamente crianças, estão expostas ao metilmercúrio pela ingestão de peixes. Foi desenvolvido um estudo seccional, comparativo, para avaliar o desempenho de dois grupos de crianças ribeirinhas de 3 a 7 anos de idade na realização de uma bateria de testes de desenvolvimento neurológico. Um grupo estudo composto de crianças expostas a moderados níveis de mercúrio $(n=75)$ e um grupo controle $(n=134)$ de crianças que diferiam do primeiro grupo por uma ingestão menor de peixe. O estudo incluiu questionário, coleta de amostras de cabelo para determinação de mercúrio total e avaliação do desempenho das crianças na realização dos testes. As crianças do grupo estudo apresentaram maior média de concentração de mercúrio no cabelo $\left(5,37 \pm 3,35 \mu \mathrm{g} \cdot \mathrm{g}^{-1}\right)$ em comparação com o grupo controle $\left(2,08 \pm 1,37 \mu g . g^{-1}\right)$. Observou-se uma elevada proporção de crianças que apresentaram desempenhos considerados como "não normais" em ambos os grupos, evidenciando que os resultados não poderiam ser relacionados com a exposição ao mercúrio e as limitações do uso deste tipo de teste para crianças ribeirinhas.

Mercúrio; Intoxicação por Mercúrio; Sistema Nervoso; Criança

\section{Contributors}

L. M. B. Tavares contributed to the study design, data collection, and analysis of results. V. M. Câmara collaborated in the study design and analysis of results. O. Malm participated in the measurement of mercury concentration in hair samples and analysis of the results. E. C. O. Santos contributed to the analysis of the results.

\section{Acknowledgments}

This study was financed by the Brazilian National Research Council (CNPq). 


\section{References}

1. Guimarães JRD, Meili M, Hylander LD, Silva EC, Roulet M, Mauro JBN, et al. Mercury net methylation in five tropical flood plain regions of Brazil: high in the root zone of floating macrophyte mats but low in surface sediments and flooded soils. Sci Total Environ 2000; 261:99-107.

2. Hacon SS, Farias RA, Campos RC, Argento RR, Valente, J, Wasserman J. Current scenarios of human exposure to mercury in the northern region of Mato Grosso, Amazon Basin. Journal of Environmental Sciences 2003; 10:121-34.

3. Choi BH, Lapham LW, Amin-Zaki L, Saleem T. Abnormal neuronal migration, deranged cerebral cortical organization and diffuse white matter astrocytosis of human fetal brain. A major effect of MeHg poisoning in utero. J Neuropathol Exp Neurol 1978; 37:719-33.

4. Agency for Toxic Substances and Disease Registry. Toxicological profile for mercury. Atlanta: U.S. Public Health; 1999.

5. Asmus CF, Ruzany MH. Riscos ocupacionais na infância e adolescência. Uma revisão. J Pediatr (Rio J) 1996; 72:203-8.

6. Myers GJ, Davidson PW, Shamlaye C. A review of MeHg and child development. Neurotoxicology 1998; 19:3131-8.

7. Santos ECO, Jesus IM, Brabo ES, Loureiro ECB, Mascarenhas AFS, Weirich J, et al. Mercury exposures in riverside Amazon communities in Pará, Brazil. Environ Res 2000; 84:100-7.

8. Grandjean P, White R, Nielsen A. MeHg neurotoxicity in Amazonian children downstream from gold mining. Environ Health Perspect 1999; 107: 587-91.

9. Pacheco-Ferreira H. Mercúrio na Amazônia: Efeitos à saúde nas populações ribeirinhas [Tese de Doutorado]. Belém: Núcleo de Altos Estudos da Amazônia, Universidade Federal do Pará; 2001.

10. Davidson PW, Myers GJ, Cox C, Shamlay C, Gao P, Axtell C, et al. Association between prenatal exposures to methylmercury and developmental outcomes in Seychellois children: effect modification by social and environmental factors. Neurotoxicology 1999; 20:833-42.

11. Grandjean P, Weihe P, White RF, Debes F. Cognitive performance of children prenatally exposed to safe levels of MeHg. Environ Res 1998; 77:16572 .

12. Cordier S, Garel M, Mandereau L, Morcel H, Doineau P, Gosme-Seguret S, et al. Neurodevelopmental investigations among MeHg-exposed children in French Guiana. Environ Res 2002; 89:1-11.
13. Lebel J, Mergler D, Branches F, Lucotte M, Amorim M, Larribe F, et al. Neurotoxic effects of lowlevel MeHg contamination in the Amazonian basin. Environ Res 1998; 79:20-32.

14. Lefèvre LB. Exame neurológico evolutivo do préescolar normal. São Paulo: Editora Sarvier; 1976.

15. Instituto Brasileiro de Geografia e Estatística. Censo demográfico de 2000. Rio de Janeiro: Instituto Brasileiro de Geografia e Estatística; 2001.

16. Yokoo EM. Avaliação da exposição ao metilmercúrio na população ribeirinha da Baixada Cuiabana no Pantanal Mato-grossense, Brasil [Tese de Doutorado]. Rio de Janeiro: Instituto de Medicina Social, Universidade do Estado do Rio de Janeiro; 2001.

17. Hylander LD, Pinto FN, Guimarães JRD, Meili M, Oliveira LJ, Silva EC. Fish mercury concentration in the Alto Pantanal, Brazil: influence of season and water parameters. Sci Total Environ 2000; 261:9-20.

18. Bastos WR, Malm O, Pfeiffer WC, Cleary D. Establishment and analytical quality control of laboratories for Hg determination in biological and geological samples in the Amazon-Brazil. Ciênc Cult 1998; 50:255-60.

19. Nakagawa R. Concentration of mercury in hair of Japanese people. Chemosphere 1995; 30:127-33.

20. Silva DSC. A questão social na Baixada Cuiabana: uma análise do perfil social em seis comunidades ribeirinhas [Monografia de Especialização]. Cuiabá: Instituto de Ciências Humanas e Sociais, Universidade Federal do Mato Grosso; 1999.

21. Mergler D. Review of neurobehavioral deficits and river fish consumption from the Tapajós (Brazil) and St. Lawrence (Canada). Environ Toxicol Pharmacol 2002; 12:93-6.

22. Arenz KH. Filhos e filhas do Beiradão. A formação sócio-histórica dos ribeirinhos da Amazônia. Santarém: Faculdades Integradas do Tapajós; 2000.

23. Santos ECO, Rosa JFT, Jesus IM, Loureiro ECB, Santos RAO, Bidone EA. A saúde das populações da Amazônia brasileira. In: Yazabál L, Espinal C, Aragon LE, organizadores. Enfoque integral de la salud humana en la Amazonia. Caracas: Universidad Central de Venezuela, Associación de Universidades Amazónicas; 1992. p. 95-139.

24. Coimbra Jr. CEA. Ecologia humana e epidemiologia na Amazônia. Uma abordagem bioantropológica. In: Neves WA, organizador. Origens, adaptações e diversidade biológica do homem nativo da Amazônia. Belém: Museu Paraense Emilio Goeldi; 1991. p. 179-92.

Submitted on $07 /$ Jun/2004

Final version resubmitted on 29/Sep/2004

Approved on 05/Oct/2004 